\title{
A Discourse Analysis of South Park's PC Principal
}

\author{
Silvia Branea ${ }^{1}$ and Teodor Dumitrache ${ }^{2}$ \\ ${ }^{1}$ Faculty of Journalism and Communication Studies, ${ }^{2}$ Faculty of Sociology and Social Work, \\ University of Bucharest, Romania
}

\begin{abstract}
Дискурс анализ на принципите на политическата коректност в „Саут парк“ Силвия Бранея ${ }^{1}$ и Теодор Димитраче ${ }^{2}$

${ }^{1}$ Факултет по журналистика и комуникационни науки, ${ }^{2}$ Факултет по социология и социална работа, Букурещки университет, Румъния
\end{abstract}

\begin{abstract}
Author notes
Silvia Branea (iD https://orcid.org/0000-0002-0020-2943; Teodor Dumitrache https://orcid.org/0000-0001-6901-816X

The authors declared no potential conflicts of interest concerning the research, authorship, and publication of this article. The authors received no financial support for the study, origin, and dissemination of this article.

Correspondence concerning this article should be addressed to Silvia Branea, Faculty of Journalism and Communication Studies, University of Bucharest, 1-3 Iuliu Maniu, Leu Complex, Building A, $6^{\text {th }}$ Floor, sector 6, Bucharest, 061071, Romania. E-mail: silvia.branea@fjsc.ro
\end{abstract}

\section{Бележки за авторите}

Силвия Бранея (D) https://orcid.org/0000-0002-0020-2943; Теодор Димитраче https://orcid.org/0000-0001-6901-816X

Авторите декларират, че нямат финансова подкрепа и потенциален конфликт на интереси по отношение на авторството и публикуването на тази статия.

Кореспонденцията, относно статията може да бъде адресирана до Силвия Бранея, Факултет по журналистика и комуникационни изследвания, Университет в Букурещ, 1-3 ул.Iuliu Maniu, комплекс Leu, сграда A, шести етаж, сектор 6, 061071, Букурещ, Румъния. Електронна поща: silvia.branea@fjsc.ro 


\begin{abstract}
This research aims to expose how South Park, a polemical entertainment program, deals with some of the most socially divisive topics from 2015 onward, thus establishing a new type of criticism that had been, for a long time, specific to news media only. The methodology used for analyzing the reflection of the political correctness paradigm is scientific narration. The actions of an autocratic persona, PC Principal, are interpreted during three relevant episodes (\#1, \#5, and \#8) of the $19^{\text {th }}$ season. The personification of censorship through the naïve Butters, an obedient schoolboy turned into a humble clerk serving PC Principal's overzealous fight for his idea of equal rights, can remind one of Hanna Arendt's work "Eichmann in Jerusalem: A Report on the Banality of Evil." Thus, people who blindly follow orders without questioning the imposed regime might have a more significant negative influence than dictators themselves. As tolerance is becoming a feature of selfishness rather than a noble human attribute due to increased competitiveness, abnormally creating the circumstances to make one more socially visible, South Park often sanctions the excessive flaws of the liberal doctrine, exposing the various absurdities can arise from such biased behaviors. Even though the show depicts thoroughly grotesque images, the authors seem to balance them with moral teachings. The present study intends to highlight the need for an alternative to formal debates regarding social issues to avoid ideological bias.
\end{abstract}

Keywords: media studies, cultural studies, political correctness, television, popular culture

\title{
Резюме
}

Статията има за цел да разкрие как полемичната развлекателна програма, „Саут парк“ борави с някои от най-социално разделителните теми от 2015 г. насам, като установява нов тип критики, които бяха дълго време специфични само за новинарските програми. Методологията, използвана за анализ на отражението на парадигмата за политическа коректност, е научнен наратив. Действията на автократична персона - Принципал на политическата коректност, се интерпретират по време на три съответни епизода (\# 1, \# 5 и \# 8) от 19-ти сезон. Олицетворението на цензурата чрез наивния Бътърс, послушен ученик, превърнат в смирен чиновник, обслужващ прекалено ревностната борба на Принципала на политическата коректност, свързана с идеята му за равни права, би могла да напомни за едно от произведенията на Хана Аренд „Айхман в Йерусалим „Репортаж за баналността на 
злото“. По този начин хората, които сляпо следват заповедите, без да поставят под въпрос наложения режим, биха могли да имат по-голямо отрицателно влияние от самите диктатори. Тъй като толерантността се превръща по-скоро в егоистична черта, а не в благороден човешки атрибут поради повишената конкурентоспособност, създавайки необичайни обстоятелства да направи човек по-видим в социално отношение, в „Саут парк“ често се санкционират прекомерните недостатъци на либералната доктрина, излагайки различни абсурди, които могат да възникнат от такива предубедени поведения. Въпреки че шоуто изобразява старателно гротескни образи, авторите изглежда ги балансират с морални учения. Настоящото проучване има за цел да подчертае необходимостта от алтернатива на официалните дебати по социални теми, за да се избегне идеологическа пристрастност.

Ключови думи: медийни изследвания, културология, политическа коректност, телевизия, популярна култура

\author{
ARTICLE INFO: \\ Original Article \\ Received: 05, 05.2020 \\ Revised: 10, 05.2020 \\ Accepted: 17, 05.2020
}




\section{A Discourse Analysis of South Park's PC Principal}

South Park is an animated television series rated TV-MA (mature audience) in the United States. Thus, due to its strong language and imagery, it is not appropriate for children. The American show follows the misadventures that four Colorado mountain town schoolboys go through. The satire created by Trey Parker and Matt Stone displays a universe in which the individuals look like cardboard cut-outs. Moreover, they maintain a consistent behavior throughout the seasons. We can easily assert that the imaginary intermingles with the grotesque and the humorous is a world where the imaginary intermingles. The use of a narrow palette of bright colors seems industrial, and the size of some anatomical parts, like heads or eyes, is exaggerated. South Park is based on the deconstruction of current American vices, and most of the time, this deconstruction is generated by the very four protagonists. They repeatedly, often involuntarily, discover and retrace humankind's road to reach the exact way of thinking satirized by the series. In this respect, South Park children behave similarly to those described in the novel "Lord of the Flies." Being one of the most famous American TV series and achieving cult status, South Park manages to spread its references and phrases across the public space, somehow anticipating the internet memes frenzy of the 2010s.

Starting with the show's 19th season, which premiered fall 2015, South Park's creators decided to focus even more than before on the political correctness phenomenon, thus delivering a new character, that of PC Principal, the head of the school where the four boys study. The PC acronym refers to political correctness throughout all episodes. A politically correct person primarily considers that language or action regarded as offensive (mostly by people belonging to certain minorities) should be avoided. Politically right people are cautious not to offend or disappoint a group that could suffer due to their gender, race, ethnicity, religion, or physical features. Due to the topics the show deals with, political correctness is related to progressivism instead of conservatism. Thus, using the term "politically correct," especially in a derogatory way, would probably appeal to conservative views. However, it remains uncertain whether ridiculing the concept and the false actions performed in its name, have drawn the public attention away from real situations of discrimination and social injustice. The clear fact is that the term "PC" was used in political debates and the entertainment industry. Persistent critics of political correctness might argue that repeatedly using this paradigm as a political weapon is due to arousing contradictions, thus discouraging freedom of speech by imposing an agenda viewed as appropriate. 
In contrast, other points of view are simply demonized. This perception tries to find the causes of the problematical evolution of political correctness within the theories of Herbert Marcuse, one of the founders of the Frankfurt School of Critical Theory. Political correctness first established itself as an ideology that attempted to bring an irreversible changing of the outlook upon society, leaning toward anthropological relativism. By engaging the image vector in the public sphere, political correctness advocates manage to build realistic expectations concerning socially approved values and questionable expectations and practices. The militancy in favor of this movement has focused upon language. In this respect, postmodernism provides the basis for axiological pluralism. Thus, it might be interesting to notice how Jean-François Lyotard continues Ludwig Wittgenstein's studies on discourse, highlighting the wordplay. Just like any other game, discourse can establish its own rules and conventions.

Consequently, any line the speaker delivers is similar to a chess move. Lyotard compares speech acts to fighting; this is why they belong to agonistics, rather than communication. But the purpose of fighting is not merely the victory of a speaker against the other. The play-on-words also has a humorous part. It is meant to generate pleasure, but at the same time, it cannot be separated from combat, the French philosopher argues. According to Lyotard, "agonistics" presupposes a state of trouble, and do not define an established philosophical doctrine, but a practice.

Furthermore, we are already involved in agonistics; we are not just witnesses or judges but also active participants in this everyday fight, with no chance for an alibi. Agonistics appeal to responsibility, but with a complete lack of planning, Lyotard adds. It is similar to writing a sentence, as if naturally moving the whole array of words to the next proposition, thus creating a state of trouble that cannot be denied unless justice is evaded (Lyotard, 1979/1984).

Naturally, the concept of political correctness is tightly bound to the Feminist Movement's branches and advocates of ethnic, cultural, or racial minorities. Critics of political correctness might consider that radical PC activists want to apply sanctions to those who do not obey and provide privileges for their favor. Undoubtedly, the values displayed by the followers of political correctness are tolerance, multiculturalism, and empathy. However, such ideas, if forcefully, neglectfully, or deceitfully spread across the globe, can lead to an approach according to which deeply-rooted beliefs of the Western world, such as Christianity, family values, patriotism, heredity, or customs, are in danger of becoming obsolete or even frowned on. Instead, they might be replaced by other concepts, such as exchange, affirmative action, and diversity. As a speech 
figure, personification is often encountered in satires, and South Park makes no exception. The sitcom creators adopt social concepts and then reshape them, often anthropomorphically, within the universe they invented. It is the case of the political correctness portrayed by PC Principal, an educated youngster, but with a limited perception of life, who owes his academic career to the fact that he restricts and humiliates those who do not adhere to his progressive moral code. The creators hid a few subtle clues about PC Principal's personal life which somehow foreshadow the events: although he is from Vermont, a place commonly regarded as being one of the most liberal, he graduated from the A\&M in Texas, a state once considered a fiefdom of the Republican Party, but which is now in jeopardy.

PC Principal is introduced in the show in late 2015, precisely in the middle of the controversy caused by the home rape scandal involving comedy actor Bill Cosby (referenced in episode 1 of the $19^{\text {th }}$ season, "Stunning and Brave"). At that moment, the general media opinion was supportive of the politically correct culture, but South Park catered to those displeased with this agenda. Thus, PC Principal replaces the headmistress of South Park Elementary, Principal Victoria, following a decision that was not based on the grounds of competence. As the former principal would later reveal, she was not fired, but replaced, intentionally leaving room for speculation and even conspiracy theories. Reality's dichotomous vision is present in the societal organization's debates, and even in those concerning extracurricular matters. The screenwriters managed to create a strong role, representing the social justice warrior (abbreviated SJW, a pejorative term for radical activists that promote political correctness). The new head of the school is rendered in a caricature-like manner. PC Principal is not afraid to use verbal or even physical violence in case someone questions his views. He believes that his perception of reality is the correct one and, even if he does not admit it, his actions show determination to break any law or rule to impose his point of view, not unlike an autocrat. PC Principal is, undoubtedly, presented in the show as being a hypocrite, especially when his actions are repudiated by the very victims of oppression, which he pretends to protect. As for his reaction to criticism and doubts, we can distinguish between two situations.

On the one hand, when PC Principal faces verbal opposition from members of the majority (white, capitalist heterosexual men, as the PC community of South Park, label them), the new head of the school resorts to violence to preserve the progressive status quo. What is highlighted here is that the impersonator of a politically correct activist does not stick to the cause, thus immorally 
profiting due to the imposed political agenda. Therefore, the PC Principal becomes a privileged caste member, and all he wants is a higher social position. Still, while fighting for it, he diminishes the power of those who suffer the consequences of persecution. On the other hand, when facing hostility from leaders of the minorities, PC Principal suddenly feels uncomfortable, begins to stammer, calls his fellow activists for backup, and adopts a defensive, even submissive posture. The principal's falsity is confirmed by situations such as the one in which Jimmy Valmer, a South Park Elementary schoolboy who is disabled, refuses to abridge the newspaper he was editing, as he allows the word "retarded" used by a colleague in an interview.

Moreover, PC Principal invites another disabled child, Nathan, to lecture Jimmy. In an overstated manner, Nathan exposes the hardships he has gone through. When confronting Jimmy in private, Nathan admits that he exaggerated his disability because "a war is coming," He wants to make sure he is "on the right side." PC Principal is infuriated when he finds out that Jimmy had not obeyed the orders to sanitize the newspaper. The head of the school and his politically correct brethren try to prove his innocence, stating that minor verbal aggression uttered by someone ruled by anger does not stand for a negative bias toward disabled people. After a brief discussion, they all comfort themselves agreeing that sometimes the victim empathizes with the aggressor; therefore, it is their rightful duty to save Jimmy even against his own will.

Contrary to his discourse, PC Principal prefers weakened minorities. This allows him to play the savior and steal the limelight. Tolerance becomes more and more a feature of selfishness rather than a common-sense attribute. Moreover, it abnormally develops a tool used to make one more socially visible. In essence, South Park repeatedly unfolds a specifically liberal moral code that ironically sanctions this doctrine's excessive flaws. The ethical perspective is what makes the show thought-provoking, even though it depicts thoroughly grotesque images. The foremost preoccupation of the politically correct group of young people that settled down in South Park is living together in a conspiracy house and planning methods of harassing those who do not conform to their strict guidelines. They test all those who intend to become followers of their political correctness group and organize loud parties, just like fraternities on university campuses. Another element of humor is the orthography of the fraternity's name, as Latin-adjusted Greek letters are used to emphasize the shallowness of their thinking.

Furthermore, PC Principal's sports sunglasses are also a unique visual feature. Even if they are an accessory meant to differentiate him, occasionally, members of the fraternity can be seen 
wearing the same sunglasses, mimicking the intelligence agents' look. This might hint at the occult, yet ridiculous aspect of the group. PC Principal's genderless quintuplets, referred to as "PC babies" (introduced after the 19th season), have also shared this detailed look ever since they were born. PC babies mock individual social justice warriors and their allegedly noisy protests regarding the state of the nation. PC babies were taken due to an undisclosed affair between PC Principal and his deputy, a fierce member of the feminist community who rejects not only the slightest sign of chivalry but also rebukes the initiators of such actions. The concept and the manifestation of the radical political correctness are based on isolating the individuals and placing them in groups that should act as safety nets to avoid any question-arising experience. That individual, held captive in the system, is permanently assured that no one can endanger the relaxed state they are obliged to enjoy.

The relationship between political correctness and space led to the concept of "safe space," which, in South Park, is an imaginary individual space, guarded by censorship, where no one can be offended, contradicted, or doubted. You are allowed to express only positive opinions about someone while you are in their safe space. In episode 5 of the 19th season, "safe space" is exemplified by presenting Eric Cartman, one of the show's four leading parts, as a victim. Cartman, a child, coping with obesity, models for a gym-inspired photo-shoot, while bragging about having a fit and muscular body. After proudly posting the images on social media, he receives adverse reactions and offenses. The boy complains to the PC Principal, who decides that a responsible pupil should be assigned to filter the negative messages that Cartman receives in virtual reality. The job is refused by all children, even at the expense of school detention. Finally, the position is attributed to Butters, the most show's most naïve character. Butters accepts only because, for him in particular, detention at school would mean severe punishment at home, as he is raised by a family that tries to maintain a profound conservative appearance. Thus, Butters becomes a censor, a simple clerk just doing his job, hired by an oppressive system. PC Principal is impressed by Butters' work and asks him to filter all mean messages received by a plus-size model agency and some celebrities. While all these clients of censorship services are pleased with each of them in their existential bubble, reality makes its debut as a negative and amusing anthropomorphized character. Reality is portrayed in a vaudevillesque style, wearing a cape and a cylinder hat, while using the gestures and phrases. Reality endangers everyone's safe space and proves that life cannot be utopian. The confrontation between the two sides occurs on the scene of 
a musical and uses cliché Broadway choreography. The cliché is the strongest weapon of standardization, a uniformity reached through consensus, as discussed by Erich Fromm in "The Sane Society." Here, the author rhetorically asks himself what would constitute one's reason for showing gratitude to the group they belong, if not the very fact that they doubt their acceptability, doubled by false acceptance (Fromm, 1955/2001). It seems like Butters works too much, as he ends up being exhausted and incapable of dealing with so much hatred and false acceptance. He experiences hallucinations of being chased and bullied by the personified reality, and eventually, he jumps out of one of the school windows and is taken to hospital. Once more, South Park changes the paradigm and exposes the ironic side of things. During the same episode, another narrative line follows Randy's actions, father to one of the children. Randy claims to be the one who gentrified the town by facilitating opening an organic products chain store and developing an exclusive residential neighborhood. So it comes as a shock for this schoolboy's father to be publicly humiliated by the shop assistant at the organic products store for not donating a dollar to needy children in Africa; yet, he buys beer and frozen pizza. This way, South Park tries to mirror and develop new opposing concepts within its universe in response to what happens in the real world. In this example, "body shaming" is countered by "charity shaming," showing that virtually any community can apply a model of activism tailored to their needs only while ignoring others' needs. The lachrymatory fundraising campaigns are mocked and reinterpreted. South Park makes perfect use of reductio ad absurdum to explain its ideology; a female pop singer running a campaign that promotes the use of tablet devices among children living in third world countries complains that she is abusively considered overweight and that not everybody can be as slim as malnourished people. Furthermore, Randy launches a campaign called "Shameless America," using yet another wordplay, which, contrary to what many might expect at first, advocates for victims of political correctness and common sense, such as those who do not recycle or do not keep an orderly line. This is not the first time Randy turns a bad public image into a good one. Randy is harshly criticized for mistakenly addressing an offensive word to the African-American community in episode 1 of the $11^{\text {th }}$ season, aired March $7^{\text {th }}$ 2011. What did Randy do after that? He played the victim, found allies among celebrities accused of the same wrongdoing, and managed to obtain a court ban on the offensive terms used against him as a result of his mistake. Moreover, Randy went on to offer scholarships for children raised in the community he had previously offended. Like in the episode described above, Randy rapidly becomes a philanthropist, seeking publicity to guarantee social 
acceptance. He even organizes a charity ball interrupted by the dramatis personae called reality, who goes on stage to unravel the supposed hypocrisy. Reality states that the world is not an art school campus, and we take for granted this spoiled lifestyle. Eventually, reality tells everyone present at the ball how the burnout has affected little Butters, the schoolboy who worked tirelessly to delete all the negative comments. Randy, humorously missing the point, proposes that Butters should not suppress the messages all by himself. The workload should be split between poor children from third-world countries, who will each receive an iPad, specially designed for this task.

At the end of the episode, Censorship, interpreted by Butters, publicly executes reality by hanging. Butters' impersonation of censorship can remind us of Hanna Arendt's work "Eichmann in Jerusalem: A Report on the Banality of Evil," in which the author unveils the lack of remorse shown by those who follow the orders, justifying their obedience by the need to apply the law as correctly as possible. These people might have a more significant negative influence than dictators themselves. This clash between the two opposing sides is represented by the conflict between Cartman and the PC Principal. The school children ask Cartman to put an end to the principal's hypocritical dictatorship. After watching all seasons, one can conclude that Eric Cartman is a child with a well-developed entrepreneurial spirit. He ignores everyone when it comes to reaching his purpose. His friends are just the result of circumstance, and he repeatedly engages in manipulation tactics, blackmail, victimization, intimidation, and extortion. Cartman continually offends people and behaves like a greedy, ruthless capitalist. It does not matter to him what self-image he projects, as long as he benefits from it.

Moreover, he does not enjoy fair-play and tries to cheat his way through as much as he can, whenever he can. Cartman's behavior is toxic, even blamable, but he is doubtlessly depicted as a rightist, yet not always a traditionalist or a familist, but an opportunist. Cartman does not participate in small civil or political actions because he thinks it is a useless fight. Instead, he heads up directly to the source, to the capital. He is directly opposed to Kyle, the idealist, whom he envies on wealth and cultural legacy. Therefore, it is not surprising that the show was appreciated by psychology and psychopathology scholars for its well-defined characters. While some authors examine how students, in an advanced psychopathology course, used symptom-based and traitbased methods to conceptualize child antisocial behavior using Cartman as a subject (Yalch et al., 2016), others have used South Park to study the way their students could get familiar with critical thinking by following the psychological concepts illustrated in the sitcom (Lanagan-Leitzel et al., 
2018). The series stirred the interest of some psychology professors. Still, its plot also contains a large amount of footage to be analyzed in the light of such an exciting topic like excessive political correctness. Cartman takes up his mission to dethrone PC Principal and tries to frame him up a rape scene. While revengefully beating him up, the headmaster lectures his enemy on not using Italian origin words that might have mafia-related connotations, because this is not politically correct. On his hospital bed, Cartman resigns and accepts PC Principal's views, but only until he learns that Kyle is now the main target of the PC group. Kyle is blamed for not admitting that Caitlyn Jenner (formerly known as Bruce Jenner) is a hero for her courage to choose her gender. Cartman prepares his assault on the PC house and stereotypically brings hundreds of pregnant women of Mexican descent, Syrian refugee children, and taco launchers. He does all this because he knows that the PC community feels uncomfortable when dealing with the real problems of the minorities they claim to defend.

In the 19th season, parallel to PC Principal's ascension to power, South Park tackles the counter-reaction to political correctness, anticipating the pro-Trump sympathy wave. Nevertheless, even the US presidency has to have something in common with the local school in the South Park universe. Therefore, instead of assigning a Donald Trump role, the cartoon uses Mr. Garrison, a South Park Elementary teacher, to run for President. The teacher is famous for being a biologically, a man who underwent a sex-change operation to become a woman. For all the trouble he created after learning that he cannot have an abortion after that. He then attempted to regain his lost sexual organ by replacing it with a lab-grown genetically modified mouse. Even though all this chain of events appeals to rights fervently defended by liberals, the show always presents Garrison in the company of Republican supporters, while having an emphatic tooth-andnail-fight attitude disclosing his homophobic and racist behavior. Garrison's campaign partner for the presidential elections is, somewhat unexpectedly, Caitlyn Jenner, the politically correct heroine of the South Park community. Jenner's role in the series is closer to that of a future First Lady. Thus, an odd but purely political couple is created.

Both partners experience a personal sexual identity crisis. Both cannot help predisposing toward xenophobia, homophobia, and racism, for in the cartoon program, Jenner unconditionally supports the hate speech promoted by Garrison. The producers intend to illustrate the top political misalliance where political doctrines do not seem to matter, but only mutual interest. As deduced from past episodes, when it comes to elections, the citizens have only two options to choose from: 
a "Giant Douche" and a "Turd Sandwich." These mascots have become leitmotifs in electionrelated installments. Despite the explicit language, Garrison is not presented as a healthy person. On the contrary, he is terrified by becoming President, claiming that he cannot keep promises such as building a wall at the Mexican border or chasing away migrant people, especially members of the Muslim community. These ideas were most probably developed on rumors that Donald Trump might not have wanted to win the presidential election (Forbes, 2015).

The end of the 19th season reveals the hidden agreement between the politically correct community of South Park and the online advertisements that evolve to a point where they achieve human form, as we can see in episode 8 of the $19^{\text {th }}$ season, "Sponsored Content." Jimmy Valmer, as the editor of South Park Elementary newspaper, is faithful to journalism. Still, he also adopts a restrictive ethical code that rejects any kind of endorsement, even product placement articles. The school newspaper, a sort of the last stronghold in the war against commercials, becomes a more desired advertising space. Yet, Jimmy rejects millions of dollars as an offer for promoting business for a vital insurance company and is held at gunpoint by the company negotiator. Jimmy is told that this war is impossible for him to win because the more people try to avoid commercials, the more the latter evolve and become more intelligent, finding new persuasion methods. Once more, the program hints at the fact that economic interests overtake the political ones. PC Principal's broken image is partially restored by the end of the season when he finds out about the involvement of these human-form advertisements and rebels against them.

The capability of doubting and testing the strength of a concept is beneficial in all nonauthoritative societies. This process can be observed and studied in the severe public sphere and humorous one (that of entertainment). There is a significant example in this respect: "The Dictator" (1940) featuring Charlie Chaplin in the leading role bravely mocks fascism and anti-Semitism. As seen in the three South Park episodes analyzed in this study, the character's facts highlight some of the dangers of assuming political correctness with a sleepy conscience. Such risks would be the uniformity of thinking, the emphasis on "language crimes," and the public display of private life aspects. Applying the political correctness paradigm has not been easy. It got swayed and eventually created a climate for chameleonic adaptation manifested by corporate campaigns that take advantage of any ideology. The paradigm was transformed into a political platform used to attract and keep the public trapped in mythologies constructed around the otherwise noble political correctness concept. There might be concerns that advocates of political correctness wish to 
establish a social and cultural leveling within a world that lacks a scale of values. Some authors might agree there is a particular initial need for an authority to exist to acknowledge and respect diversity. Still, others might consider that the correct perception of the world is monopolized (Cepeda-Mayorga, 2017). One might ask: "How valid are, from the audience's perspective, the representations brought to light by the producers of this animated sitcom? What is the validity of the same representations for people living outside the US, as they can only find out about the issues in question from secondary sources such as media, social networks, or blogs?" Of course, we cannot put an equal sign between formal or official public debates on political correctness and fictional constructions that personify, through specific characters, different points of view upon this paradigm. This study is meant to punctuate that there is an alternative to formally debating public interest issues when we can see a strongly marked gathering of the public toward some areas less exposed to political or academic views to avoid any kind of ideological bias. As for the South Park producers' opinions, we cannot assume that they represent the best trends in perceiving developments against or in the name of political correctness. 


\section{References}

Cepeda-Mayorga, I. (2017). Political correctness from a border reason: Between dignity and the shadow of exclusion. Philosophies, 2(2). https://doi.org/10.3390/philosophies2020013

Fromm, E. (1955/2001). The sane society (2nd ed.). Routledge.

Lanagan-Leitzel, L. \& Diller, J. W. (2018). Teaching psychological critical thinking using popular media. Scholarship of Teaching and Learning in Psychology, 4(2), 120-125. https://doi.org/10.1037/st10000112

Lyotard, J-F. (1979/1984). The Postmodern Condition: A Report on Knowledge. Theory and History of Literature, vol. 10. University of Minnesota Press.

Yalch, M. M., Vitale, E. M., \& Ford, J. K. (2016). Diagnosing Cartman: Psychology students' use of symptoms and traits to assess child antisocial behavior. The teaching of Psychology, 43(3), 227-231. https://doi.org/10.1177/0098628316649480

Forbes. (2015, November 10). "Does Donald Trump Really Want To Be President? | Forbes."

[Video file]. https://www.youtube.com/watch?v=ETfFkv2rZlk. 